\title{
PEMODELAN PENGARUH IKLIM TERHADAP ANGKA KEJADIAN DEMAM BERDARAH DI KOTA AMBON MENGGUNAKAN METODE REGRESI GENERALIZED POISSON ${ }^{*}$
}

\author{
Ferry Kondo Lembang ${ }^{1}$, Eysye Alchi Nara ${ }^{2}$, Francis Yunito \\ Rumlawang ${ }^{3}$, and Mozart Winston Talakua ${ }^{4}$ \\ 1Jurusan Matematika FMIPA Universitas Pattimura, Indonesia, ferrykondolembang@gmail.com
2Jurusan Matematika FMIPA Universitas Pattimura, Indonesia, eysyenara27@gmail.com
3Jurusan Matematika FMIPA Universitas Pattimura, Indonesia, rumlawang@gmail.com
4Jurusan Matematika FMIPA Universitas Pattimura, Indonesia, ocat_talakua@yahoo.com
}

Indonesian Journal of Statistics and Its Applications (elSSN:2599-0802)

Vol 3 No 3 (2019), 341 - 351

Copyright (@ 2019 Ferry Kondo Lembang, Eysye Alchi Nara, Francis Yunito Rumlawang, and Mozart Winston Talakua. This is an open-access article distributed under the Creative Commons Attribution License, which permits unrestricted use, distribution, and reproduction in any medium, provided the original work is properly cited.

\begin{abstract}
Dengue Hemorrhagic Fever (DHF) is one of the dreaded diseases of the transition season. DHF is a disease found in tropical and subtropical regions that caused by Dengue virus which is transmitted through Aedes mosquitoes. According to the World Health Organization (WHO) data, it is stated that Indonesia is the country with the highest dengue fever case in Southeast Asia. The incidence of dengue fever in Indonesia tends to increase in the middle of the rainy season, and one of the regions in Indonesia with the high level of rainfall intensity is Ambon City. DHF cases in Ambon city increase from year to year due to the last five years the intensity of rainfall is very high. Therefore, this study aims to identify climate factors that affect the incidence of DHF in Ambon City by using Generalized Poisson Regression method. Generalized Poisson Regression is appropriately considered to analyze the causing factors DHF incidence because the rating case of DHF is usually the count data that following the Poisson distribution. The results showed that the smallest AIC value for the Generalized Poisson Regression model was 75.842 with significant variables is DHF in the city of Ambon were one month earlier, air humidity, rainfall, and air humidity two months earlier.
\end{abstract}

Keywords: climate factor, DHF, generalized poisson regression.

* Received Jul 2019; Accepted Oct 2019; Published online on Oct 2019 


\section{Pendahuluan}

Salah satu penyakit yang ditakutkan pada musim pancaroba yaitu penyakit Demam Berdarah Dengue (DBD). DBD adalah penyakit yang ditemukan di daerah tropis dan daerah subtropis yang disebabkan akibat adanya virus Dengue yang ditularkan melalui gigitan nyamuk Aedes. Indonesia merupakan negara yang dimungkinkan sebagai daerah penyebaran sekaligus daerah endemis yang menyebabkan tingginya angka penderita DBD. Menurut data World Health Organization (WHO) disebutkan bahwa Indonesia adalah negara dengan tingkat kasus DBD tertinggi se-Asia Tenggara. Kementerian Kesehatan Republik Indonesia mencatat pada bulan Januari-Februari 2016 jumlah penderita DBD di Indonesia sebanyak 8487 orang dengan jumlah kematian sebanyak 108 orang. Kejadian penyakit DBD di Indonesia biasanya meningkat pada pertengahan musim penghujan sekitar bulan Januari. Salah satu kota di Indonesia dengan tingkat intensitas curah hujan yang cukup tinggi adalah kota Ambon.

Salah satu indikator penyebab mewabahnya virus Dengue di Indonesia adalah perubahan iklim. Perubahan iklim ternyata dapat memperpanjang masa penularan DBD yang ditularkan melalui vektor dan mengubah luas geografinya, dengan kemungkinan menyebar ke daerah yang kekebalan populasinya rendah, kebutuhan ekonomi yang tidak stabil ataupun dengan infrastruktur kesehatan masyarakat yang kurang. Informasi iklim dapat dijadikan sebagai input/masukan untuk menduga tingkat resiko kejadian penyakit DBD pada suatu musim. Banyak studi yang mengatakan bahwa iklim mempengaruhi kejadian DBD salah satunya adalah penelitian oleh Hidayati (2008) yang melakukan penyusunan model kejadian DBD dengan unsur iklim (curah hujan, hari hujan dan suhu). Penelitian tersebut mendapatkan hasil output bahwa faktor curah hujan dan suhu berpengaruh terhadap kejadian DBD.

Berdasarkan informasi di atas, peneliti ingin melakukan pemodelan pengaruh iklim terhadap angka kejadian DBD menggunakan metode regresi Generalized Poisson di kota Ambon. Metode ini dapat mengatasi kasus overdispersi terhadap Angka kejadian DBD. Dalam pemodelan pengaruh iklim terhadap angka kejadian DBD di kota Ambon dengan menggunakan metode regresi Generalized Poisson dan diperhitungkan faktor time lag 1 dan 2 bulan untuk faktor iklim. Karena antara curah hujan dan jumlah penderita DBD memiliki pola osilasi yang sama, namun ada perbedaan waktu puncak (time lag) yaitu 1 sampai 2 periode. Dengan adanya perbedaan waktu tersebut dapat dijadikan acuan sebagai waktu intervensi untuk kewaspadaan DBD (Rahayu et al., 2012).

\section{Metodologi}

\subsection{Bahan dan Data}

Data yang digunakan adalah data sekunder yang diperoleh dari Dinas Kesehatan kota Ambon serta stasiun Badan Meteorologi Klimatologi dan Geofisika (BMKG) kota Ambon yang merupakan data bulanan tahun 2014 dan tahun 2015. Identitas variabel penelitian yang dilibatkan dalam penelitian ini ditunjukkan pada Tabel 1. 
Tabel 1: Variabel penelitian yang digunakan.

\begin{tabular}{ll}
\hline \multicolumn{1}{c}{ Variabel } & \multicolumn{1}{c}{ Keterangan } \\
\hline Variabel Respon $(\mathrm{Y})$ & Angka Kejadian Demam Berdarah Di Kota Ambon \\
Variabel Prediktor $(\mathrm{X})$ & $\mathrm{X}_{1}=\mathrm{Y}_{(\mathrm{t}-1)}$ \\
& $\mathrm{X}_{2}=\mathrm{Y}(\mathrm{t}-2)$ \\
& $\mathrm{X}_{3}=$ Kelembaban Udara $(\%)$ \\
& $\mathrm{X}_{4}=$ Suhu Udara $\left({ }^{0} \mathrm{C}\right)$ \\
& $\mathrm{X}_{5}=$ Curah Hujan $(\mathrm{mm})$ \\
& $\mathrm{X}_{6}=$ Kelembaban Udara $(\mathrm{t}-1)$ \\
& $\mathrm{X}_{7}=$ Suhu Udara(t-1) \\
& $\mathrm{X}_{8}=$ Curah Hujan(t-1) \\
& $\mathrm{X}_{9}=$ Kelembaban Udara $(\mathrm{t}-2)$ \\
& $\mathrm{X}_{10}=$ Suhu Udara $(\mathrm{t}-2)$ \\
& $\mathrm{X}_{11}=$ Curah Hujan $_{(\mathrm{t}-2)}$ \\
\hline
\end{tabular}

\subsection{Metode Penelitian}

Langkah-langkah analisis data yang dilakukan dalam penelitian ini adalah sebagai berikut:

a. Pengujian Distribusi Poisson Untuk Variabel Respon

Regresi Poisson merupakan salah satu regresi yang dapat menggambarkan hubungan antara variabel respon $(Y)$ dimana variabel respon berdistribusi Poisson, dan variabel prediktor $(X)$ sebagai model untuk data diskrit dan termasuk dalam model linier. Regresi Poisson merupakan penerapan dari Generalized Linear Model (GLM). Generalized Linier Model (GLM) merupakan perluasan dari model regresi umum untuk variabel respon yang memiliki sebaran eksponensial. Regresi Poisson digunakan untuk menganalisis data count (berjenis diskrit atau data membilang). Pada regresi Poisson diasumsikan variabel respon ( $Y$ ) berdistribusi Poisson (Ruliana et al., 2016).

b. Pemeriksaan Multikolinieritas

Multikolinearitas adalah sebuah situasi yang menunjukkan adanya korelasi atau hubungan kuat antara dua variabel bebas atau lebih dalam sebuah model regresi berganda. Konsekuensi jika model mengandung multikolinearitas berarti variannya akan terus naik atau membesar. Jika variansi semakin naik atau membesar maka standar error $\beta_{1}$ dan $\beta_{2}$ juga naik atau membesar. Ada beberapa cara untuk mendeteksi ada tidaknya multikolinieritas. Untuk mendeteksi ada tidaknya multikolinieritas dengan melihat nilai Tolerance dan VIF (Variance Inflation Factor) (Priyatno, 2013). Jika nilai Tolerance lebih dari 0.1 dan VIF kurang dari 10 maka pengaruh multikolinieritas dapat diabaikan.

c. Pemodelan Regresi Poisson

Pada model regresi Poisson harus dilakukan estimasi pada $\beta_{0}, \beta_{1}, \ldots, \beta_{p}$ dengan $\beta_{0}, \beta_{1}, \ldots, \beta_{p}$ adalah parameter yang tidak diketahui. Metode yang digunakan untuk menaksir parameter $\beta_{0}, \beta_{1}, \ldots, \beta_{p}$ yaitu metode Maximum Likelihood Estimation (MLE). Adapun tahapan pertama dalam melakukan pemodelan regresi Poisson adalah melakukan estimasi parameter secara serentak dan parsial. 
1) Uji Serentak parameter model Regresi Poisson

Pengujian serentak parameter model regresi Poisson digunakan untuk mengetahui ada tidaknya pengaruh variabel prediktor terhadap variabel respon (Darnah, 2011). Adapun hipotesis yang digunakan dalam pengujian ini adalah sebagai berikut :

$$
\begin{aligned}
& H_{0}: \beta_{1}=\beta_{2}=\cdots=\beta_{p}=0 \\
& H_{1}: \exists \beta_{j} \neq 0 ; \text { untuk suatu } j=1,2, \ldots, p
\end{aligned}
$$

Untuk taraf signifikan $\alpha=0.05$ dan formula Statistik Uji yang digunakan adalah sebagai berikut :

$$
G=-2 \ln \left(\frac{L(\hat{\omega})}{L(\hat{\Omega})}\right)=2[\ln L(\hat{\Omega})-\ln L(\hat{\omega})]
$$

dimana $L(\widehat{\omega})$ adalah nilai likelihood untuk model sederhana tanpa melibatkan variabel prediktor, sedangkan $L(\widehat{\Omega})$ adalah nilai likelihood untuk model lengkap dengan melibatkan variabel prediktor. Kriteria pengujian yakni tolak $H_{0}$ apabila nilai Likelihood Ratio Chi-Square $>\chi_{v, \alpha}^{2}$ atau p-value (Sig.) $<\alpha$ dengan $v$ adalah banyaknya parameter model dan $\alpha$ adalah tingkat signifikansi.

2) Uji Parsial parameter model Regresi Poisson

Pengujian secara parsial digunakan untuk mengetahui adanya variabel prediktor yang berpengaruh terhadap variabel respon yang dapat diuji secara individual (Darnah, 2011). Statistik uji yang digunakan untuk uji parsial yaitu uji Wald.

3) Interpretasi Model Regresi Poisson

Model regresi Poisson berganda adalah sebagai berikut :

$$
\ln \left(\mu_{i}\left(x_{1 i}, x_{2 i}, \ldots, x_{p i}\right)\right)=\beta_{0}+\beta_{1} X_{1 i}+\beta_{2} X_{2 i}+\ldots+\beta_{p} X_{p i}
$$

dengan $\beta_{0}, \beta_{1}, \beta_{2}, \ldots, \beta_{p}$ menyatakan parameter-parameter yang tidak diketahui.

4) Pemeriksaan Kasus Overdispersi/Underdispersi Pada Model Regresi Poisson. Dalam menganalisis data hasil count banyak ditemukan kasus data yang memiliki nilai variansinya lebih besar atau lebih kecil dari nilai rata-ratanya. Untuk menganalisis data diskrit biasanya digunakan regresi Poisson. Namun, dalam regresi Poisson asumsi yang harus dipenuhi adalah adanya equidispersi atau nilai variansinya sama dengan nilai rata-ratanya. Menurut Darnah (2011) parameter dispersi $(\phi)$ diperoleh dari rumus :

$$
\phi=\frac{\text { nilai deviance }}{d f},
$$

dimana, $d f=$ degree of freedom . Sedangkan nilai deviance diperoleh dari :

$$
\text { Deviance : } G^{2}=2 \sum_{i=1}^{n} y_{i} \ln \left(\frac{y_{i}}{\lambda_{i}}\right)
$$

Apabila nilai $\phi>0$ maka terjadi overdispersi dan apabila $\phi<0$ maka terjadi underdispersi. Overdispersi adalah kondisi dimana data variabel respon menunjukkan nilai variansi lebih besar dari nilai rata-ratanya. Sedangkan underdispersi adalah sebaliknya dimana data variabel respon memiliki nilai variansi lebih kecil dari nilai rata-ratanya. 
Overdispersi ataupun underdispersi akan menghasilkan nilai devians model menjadi sangat besar sehingga model yang dihasilkan kurang tepat. Salah satu model yang dapat digunakan untuk mengatasi masalah overdispersi ataupun underdispersi adalah dengan model regresi Poisson tergeneralisasi. Model regresi ini merupakan perluasan dari regresi Poisson dan baik digunakan dalam keadaan equidispersi, overdispersi ataupun underdispersi. Menurut Irwan \& Sari (2013) ketika model Poisson diterapkan untuk data overdispersi, menyebabkan standar error underestimate. Akibatnya, beberapa variabel prediktor menjadi tidak signifikan.

d. Pemodelan Regresi Generalized Poisson

Model regresi Generalized Poisson bertujuan untuk mengatasi masalah kasus overdispersi atau Underdispersi. Untuk tahap pertama dilakukan pemilihan model terbaik dengan melihat nilai Akaike Information Criterion (AIC) pada masing-masing kombinasi variabel prediktor dalam model regresi. AIC merupakan informasi perbedaan yang dianggap sebagai dasar kriteria untuk mengevaluasi kebaikan model sehingga pendekatan untuk distribusi benar. AIC tidak menguji model dalam bentuk biasa dalam uji hipotesis nol.

AIC dapat menunjukkan setidaknya ada beberapa model pantas dengan data yang dimiliki secara mutlak. Menurut (Melliana et al., 2013) AIC didefinisikan sebagai berikut:

$$
A I C=-2 \ln L(\hat{\theta})+2 k
$$

dimana $L(\hat{\theta})$ adalah nilai likelihood, dan $k$ adalah jumlah parameter. Nilai yang lebih rendah dari indeks menunjukkan model yang disukai, yaitu satu dengan parameter paling sedikit yang masih memberikan fit yang memadai untuk data. Jadi untuk memilih model yang terbaik yaitu dengan memilih model yang mempunyai nilai AIC terkecil (Rahayu et al., 2012).

Tahap kedua atau tahapan yang terakhir adalah melakukan pengujian serentak dan pengujian parsial parameter model regresi Generalized Poisson terbaik untuk mengetahui variabel prediktor mana saja yang memiliki pengaruh signifikan terhadap variabel respon.

\section{Hasil dan Pembahasan}

Angka kejadian DBD di Kota Ambon Periode 2014-2015 tiap bulan berdasarkan data Dinas Kesehatan Kota Ambon tercatat bahwa Bulan Februari, November, dan Desember Tahun 2015 merupakan yang tertinggi dimana berjumlah 5 kejadian. Rekapan angka kejadian DBD di Kota Ambon untuk Periode 2014-2015 tiap bulan dapat ditunjukkan pada Gambar 1.

Selanjutnya akan disajikan tahapan pemodelan Regresi Generalized Poisson untuk mendapatkan indikator iklim yang mempengaruhi angka kejadian DBD di Kota Ambon Periode Tahun 2014-2015. Adapun model yang akan dibentuk sebagai berikut:

$$
\mu=e^{\left(\beta_{0}+\beta_{1} X_{1 i}+\beta_{2} X_{2 i}+\ldots+\beta_{p} X_{p i}\right)}
$$




\subsection{Pemeriksaan Multikolinieritas}

Pemeriksaan multikolinieritas dilakukan terhadap variabel prediktor. Didalam model regresi diharapkan antar variabel prediktor tidak berkorelasi satu sama lain. Pendeteksian kasus multikolinieritas disajikan pada Tabel 2.

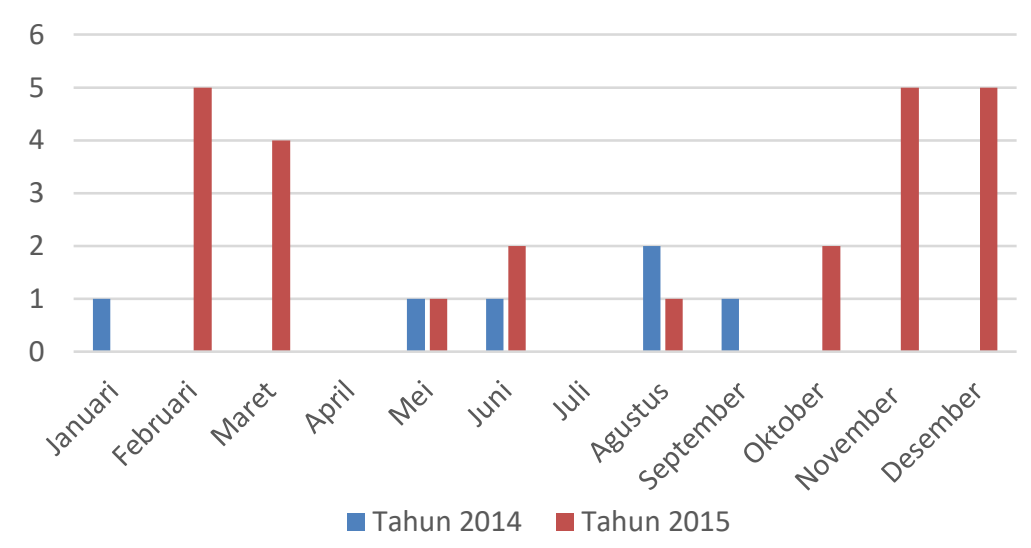

Gambar 1: Angka Kejadian DBD Di Kota Ambon Periode Tahun 2014-2015.

Tabel 2: Pemeriksaan multikolinieritas dengan Tolerance dan VIF.

\begin{tabular}{|c|c|c|}
\hline & \multicolumn{2}{|c|}{ Collinearity Statistics } \\
\hline Model & Tolerance & VIF \\
\hline $\mathrm{X}_{1}$ & 0.707 & 1.415 \\
\hline$x_{2}$ & 0.604 & 1.655 \\
\hline$x_{3}$ & 0.111 & 9.000 \\
\hline$X_{4}$ & 0.043 & 23.035 \\
\hline$X_{5}$ & 0.336 & 2.976 \\
\hline$x_{6}$ & 0.163 & 6.152 \\
\hline$x_{7}$ & 0.049 & 20.361 \\
\hline$X_{8}$ & 0.300 & 3.337 \\
\hline$X_{9}$ & 0.112 & 8.897 \\
\hline$X_{10}$ & 0.075 & 13.247 \\
\hline$X_{11}$ & 0.424 & 2.358 \\
\hline
\end{tabular}

Pemeriksaan kasus multikolinieritas menggunakan nilai VIF atau nilai tolerance. Berdasarkan Tabel 2, diperoleh bahwa ada tiga variabel prediktor yang memiliki nilai VIF yang lebih besar dari 10. Dengan situasi ini dapat dikatakan masih terdapat kasus multikolinieritas antara variabel prediktor sehingga untuk mengatasinya perlu dilakukan eliminasi variabel prediktor yang memiliki nilai VIF tertinggi yakni variabel Suhu Udara $\left(X_{4}\right)$ dengan nilai sebesar 23.035. Adapun hasil pengujian multikolinieritas dengan tidak melibatkan variabel Suhu Udara $\left(X_{4}\right)$ ditunjukkan pada Tabel 3. 
Tabel 3: Pengujian multikolinieritas tanpa melibatkan variabel suhu udara $\left(X_{4}\right)$.

\begin{tabular}{|c|c|c|}
\hline & \multicolumn{2}{|c|}{ Collinearity Statistics } \\
\hline Model & Tolerance & VIF \\
\hline \multicolumn{3}{|l|}{1 (Constant) } \\
\hline$X_{1}$ & 0.707 & 1.414 \\
\hline$X_{2}$ & 0.719 & 1.391 \\
\hline$X_{3}$ & 0.209 & 4.786 \\
\hline$X_{5}$ & 0.372 & 2.690 \\
\hline$X_{6}$ & 0.173 & 5.795 \\
\hline $\mathrm{X}_{7}$ & 0.108 & 9.266 \\
\hline$X_{8}$ & 0.310 & 3.229 \\
\hline$X_{9}$ & 0.161 & 6.210 \\
\hline$X_{10}$ & 0.115 & 8.662 \\
\hline$X_{11}$ & 0.434 & 2.303 \\
\hline
\end{tabular}

Pada Tabel 3 diperoleh hasil bahwa keseluruhan nilai VIF dari variabel prediktor tidak lebih dari 10 sehingga dapat disimpulkan bahwa tidak terdapat kolinieritas ganda (multikolinieritas) antara variabel prediktor yang akan dilibatkan dalam model. Oleh sebab itu, selain dari variabel suhu udara maka variabel-variabel lainnya telah lolos uji dan dapat diikutsertakan dalam pembentukan model regresi Poisson.

\subsection{Pemodelan Regresi Poisson}

\section{a. Uji Serentak parameter model Regresi Poisson}

Dalam pengujian serentak parameter model regresi Poisson digunakan hipotesis sebagai berikut :

$$
\begin{aligned}
& H_{0}: \beta_{1}=\beta_{2}=\beta_{3}=\beta_{5}=\cdots=\beta_{11}=0 \\
& H_{1}: \exists \beta_{j} \neq 0 ; \text { untuk suatu } j=1,2,3,5, \ldots, 11
\end{aligned}
$$

Hasil Uji Serentak menggunakan uji Chi-Square diperoleh bahwa nilai Likelihood Ratio Chi-Square $\left(G^{2}\right)$ sebesar 27.341 dimana lebih besar dari nilai $\chi_{(10 ; 0.05)}^{2}$ atau pvalue (Sig.) sebesar 0.002 yang kurang dari nilai $\alpha=0.05$ sehingga keputusan yang diambil adalah tolak $H_{0}$ artinya minimal terdapat satu variabel prediktor yang berpengaruh terhadap variabel respon dalam hal ini angka kejadian demam berdarah di kota Ambon.

\section{b. Uji Parsial parameter model Regresi Poisson}

Hasil dari pengujian serentak diperoleh bahwa minimal terdapat satu variabel prediktor yang berpengaruh terhadap variabel respon dalam hal ini angka kejadian demam berdarah di kota Ambon. Oleh sebab itu, dilakukan pengujian parsial untuk masing-masing variabel prediktor. Adapun hipotesis yang diuji dalam uji parsial parameter model regresi poisson antara lain sebagai berikut :

$H_{0}: \beta_{j}=0$ (pengaruh variabel ke-j tidak signifikan)

$H_{1}: \beta_{j} \neq 0$ (pengaruh variabel ke-j signifikan) 
Tabel 4: Pengujian estimasi parameter secara parsial model regresi poisson.

\begin{tabular}{cccc}
\hline & & \multicolumn{2}{c}{ Hypothesis Test } \\
\cline { 3 - 4 } Parameter & $B$ & $\begin{array}{c}\text { Wald Chi- } \\
\text { Square }\end{array}$ & Sig. \\
\hline (Intercept) & 32.569 & 0.464 & 0.496 \\
X $_{1}$ & 0.207 & 2.161 & 0.142 \\
X $_{2}$ & -0.232 & 1.028 & 0.311 \\
X $_{3}$ & -0.191 & 1.755 & 0.185 \\
X $_{4}$ & 0.006 & 5.194 & 0.023 \\
X $_{6}$ & -0.309 & 1.421 & 0.233 \\
X $_{7}$ & -1.198 & 2.680 & 0.102 \\
X $_{8}$ & -0.001 & 0.076 & 0.782 \\
X $_{9}$ & 0.290 & 3.181 & 0.074 \\
X $_{10}$ & 0.625 & 0.801 & 0.371 \\
X $_{11}$ & -0.006 & 2.428 & 0.119 \\
\hline
\end{tabular}

Uji signifikansi model regresi poisson dilakukan dengan Uji Wald. Berdasarkan Tabel 4, diperoleh informasi bahwa hanya variabel prediktor Curah Hujan $\left(X_{5}\right)$ yang memiliki nilai p-value sebesar 0.023 kurang dari $\alpha=0.05$. Hal ini berarti variabel curah hujan $\left(X_{5}\right)$ memiliki pengaruh signifikan terhadap angka kejadian demam berdarah di kota Ambon. Sedangkan sembilan variabel prediktor lainnya tidak memiliki pengaruh yang signifikan terhadap angka kejadian demam berdarah di kota Ambon dikarenakan memiliki nilai $\mathrm{p}$-value lebih besar dari $\alpha=0.05$.

\section{Interpretasi Model Regresi Poisson}

Berdasarkan uji parsial parameter model regresi poisson diperoleh model final regresi poisson adalah sebagai berikut :

$$
\ln (\hat{\mu})=32.569+0.006 X_{5}
$$

Berdasarkan model regresi Poisson di atas diperoleh faktor yang mempengaruhi angka kejadian DBD di kota Ambon adalah persentase curah hujan. Selanjutnya untuk pengambilan kesimpulan bahwa model Regresi Poisson ini merupakan model yang cocok untuk memodelkan angka kejadian DBD di Kota Ambon periode tahun 20142015 maka perlu dipastikan bahwa model ini bebas dari kasus overdispersil underdispersi.

\section{d. Deteksi Overdispersi/Underdispersi Model Regresi Poisson.}

Deteksi adanya kasus dispersi untuk mengetahui apakah model regresi Poisson yang diperoleh memenuhi asumsi equidispersi yakni dengan dengan syarat nilai deviance / $d b=1$. Jika deviance / $d b>1$ terjadi overdispersi, sedangkan deviance / $d b<1$ maka terjadi underdispersi. Hasil deteksi terhadap kasus overdispersi/underdispersi diperoleh nilai nilai deviance/df sebesar 1.883 dimana lebih besar dari 1 sehingga dapat disimpulkan bahwa model regresi poisson untuk angka kejadian DBD di kota Ambon periode tahun 2014-2015 mengalami overdispersi dimana tidak memenuhi 
asumsi equidispersi yang disyaratkan. Oleh karena itu, solusi untuk mengatasinya adalah dengan menggunakan Pemodelan Regresi Generalized Poisson dimana model tersebut dapat mengakomodasi parameter dispersi.

\subsection{Pemodelan Regresi Generalized Poisson Angka Kejadian DBD Di Kota Ambon.}

Model regresi Generalized Poisson bertujuan untuk mengatasi masalah kasus overdispersi. Untuk tahap pertama dilakukan pemilihan model terbaik dengan melihat nilai AIC pada model regresi. Karena terdapat sembilan variabel prediktor yang digunakan untuk pembentukan model Regresi Poisson maka didapatkan 1004 kemungkinan model. Untuk model regresi Generalized Poisson yang mempunyai nilai AIC terkecil (diambil lima terkecil) pada masing-masing kombinasi variabel disajikan pada Tabel 5.

Tabel 5: Nilai AIC kemungkinan model regresi generalized poisson.

\begin{tabular}{cc}
\hline Model & AIC \\
\hline$\varepsilon^{\beta_{0}+\beta_{1} X_{1}+\beta_{2} X_{2}+\beta_{3} X_{3}+\beta_{5} X_{5}+\beta_{9} X_{9}}$ & 75.842 \\
$\varepsilon^{\beta_{0}+\beta_{1} X_{1}+\beta_{2} X_{2}+\beta_{5} X_{5}+\beta_{6} X_{6}+\beta_{9} X_{9}+\beta_{11} X_{11}}$ & 75.979 \\
$\varepsilon^{\beta_{0}+\beta_{2} X_{2}+\beta_{3} X_{3}+\beta_{5} X_{5}+\beta_{6} X_{6}+\beta_{7} X_{7}+\beta_{9} X_{9}+\beta_{11} X_{11}}$ & 76.362 \\
$\varepsilon^{\beta_{0}+\beta_{1} X_{1}+\beta_{2} X_{2}+\beta_{3} X_{3}+\beta_{5} X_{5}+\beta_{9} X_{9}+\beta_{11} X_{11}}$ & 76.382 \\
$\varepsilon^{\beta_{0}+\beta_{2} X_{2}+\beta_{3} X_{3}+\beta_{5} X_{5}+\beta_{6} X_{6}+\beta_{7} X_{7}+\beta_{11} X_{11}}$ & 76.531 \\
\hline
\end{tabular}

Berdasarkan Tabel 5 model yang mempunyai nilai AIC terkecil adalah model regresi Generalized Poisson dengan variabel yang masuk dalam model yaitu variabel angka kejadian DBD satu bulan sebelumnya $\left(X_{1}\right)$, angka kejadian DBD 2 bulan sebelumnya $\left(X_{2}\right)$, kelembaban udara $\left(X_{3}\right)$, curah hujan $\left(X_{5}\right)$, kelembaban udara dua bulan sebelumnya $\left(X_{9}\right)$ yakni sebesar 75.842 .

\section{a. Uji Serentak Parameter Model Regresi Generalized Poisson}

Dalam pengujian Serentak Parameter Model Regresi Genrealized Poisson akan diuji hipotesis sebagai berikut :

$$
\begin{aligned}
& H_{0}: \beta_{1}=\beta_{2}=\beta_{3}=\beta_{5}=\beta_{9}=0 \\
& H_{1}: \exists \beta_{j} \neq 0 ; \text { untuk suatu } j=1,2,3,5,9
\end{aligned}
$$

Hasil Uji Serentak menggunakan uji Chi-Square diperoleh bahwa nilai Likelihood Ratio Chi-Square $\left(G^{2}\right)$ sebesar 21.530 lebih besar dari nilai $\chi_{(5 ; 0.05)}^{2}$ atau $p$-value (Sig.) sebesar 0.001 dimana kurang $\alpha=0.05$ sehingga keputusan yang diambil adalah tolak $H_{0}$ yang artinya minimal terdapat satu variabel prediktor yang berpengaruh terhadap variabel respon dalam hal ini angka kejadian demam berdarah di kota Ambon. 


\section{b. Uji Parsial Parameter Model Regresi Generalized Poisson}

Uji parsial parameter model regresi Generalized Poisson dilakukan untuk menjawab hasil uji serentak. Adapun hipotesis yang akan diuji adalah sebagai berikut:

$H_{0}: \beta_{j}=0$ (pengaruh variabel ke-j tidak signifikan)

$H_{1}: \beta_{j} \neq 0$ (pengaruh variabel ke-j signifikan)

Tabel 6: Uji Parsial Model Regresi Generalized Poisson

\begin{tabular}{ccc}
\hline & & $\begin{array}{c}\text { Hypothesis } \\
\text { Pest }\end{array}$ \\
\cline { 3 - 3 } Parameter & $B$ & Sig. \\
\hline (Intercept) & 1.695 & 0.810 \\
$X_{1}$ & 0.259 & 0.037 \\
$X_{2}$ & -0.500 & 0.054 \\
$X_{3}$ & -0.203 & 0.006 \\
$X_{5}$ & 0.004 & 0.015 \\
$X_{9}$ & 0.173 & 0.030 \\
\hline
\end{tabular}

Berdasarkan Tabel 6 diperoleh informasi bahwa 4 (empat) variabel prediktor yaitu variabel angka kejadian DBD satu bulan sebelumnya $\left(X_{1}\right)$, kelembaban udara $\left(X_{3}\right)$, curah hujan $\left(X_{5}\right)$, kelembaban udara dua bulan sebelumnya $\left(X_{9}\right)$ memiliki pengaruh yang signifikan terhadap angka kejadian demam berdarah di kota Ambon dikarenakan memiliki nilai $p$-value kurang dari $\alpha=0.05$.

\section{c. Interpretasi Model Regresi Generalized Poisson Angka Kejadian DBD Di Kota} Ambon.

Berdasarkan hasil pengujian parsial diperoleh model Regresi Generalized Poisson sebagai berikut :

$$
\ln (\hat{\mu})=1.695+0.259 X_{1}-0.203 X_{3}+0.004 X_{5}+0.173 X_{9}
$$

Dengan demikian faktor yang mempengaruhi angka kejadian DBD di Kota Ambon pada taraf signifikan $5 \%$ adalah angka kejadian DBD satu bulan sebelumnya, kelembaban udara, curah hujan, kelembaban udara dua bulan sebelumnya. Itu berarti setiap penambahan 1 orang penderita DBD pada bulan ini maka akan meningkatkan rata-rata angka kejadian DBD pada bulan berikutnya. Berarti angka kejadian DBD 1 bulan sebelumnya memiliki hubungan sejalan dengan angka kejadian DBD saat ini. Selain itu, curah hujan sekarang dan curah hujan 1 bulan sebelumnya serta kelembaban udara sekarang dan kelembaban udara 2 bulan sebelumnya juga memiliki hubungan yang sejalan dengan angka kejadian DBD, setiap penambahan $1 \mathrm{~mm}$ curah hujan maka akan meningkatkan rata-rata angka kejadian DBD pada bulan berikutnya. Setiap penambahan $1 \%$ kelembaban udara akan meningkatkan rata-rata angka kejadian DBD pada saat ini dan 2 bulan berikutnya. 


\section{Simpulan Dan Saran}

\subsection{Simpulan}

Berdasarkan hasil penelitian dapat disimpulkan bahwa faktor yang mempengaruhi jumlah angka kejadian demam berdarah dengue di kota Ambon adalah angka kejadian DBD satu bulan sebelumnya, kelembaban udara, curah hujan, kelembaban udara dua bulan sebelumnya.

\subsection{Saran}

Adapun saran yang bisa disarankan penulis yakni perlu dilakukan pembanding dengan model lain yang dapat mengatasi kasus overdispersi/Underdispersi yaitu Model Regresi Binomial Negatif yang juga merupakan metode perluasan dari regresi Poisson.

\section{Daftar Pustaka}

Darnah. (2011). Mengatasi overdispersi pada model regresi poisson dengan generalized poisson regression. Jurnal Eksponensial, 2(2): 5-10.

Hidayati, R. (2008). Model peringatan dini penyakit demam berdarah dengan informasi unsur iklim (Tesis). IPB University, Bogor (ID).

Irwan, \& Sari, D. P. (2013). Pemodelan regresi poisson dan binomial negatif pada kasus kecelakaan kendaraan bermotor di lalu lintas Sumatera Barat. Prosiding Seminar Nasional Matematika dan Pendidikan Matematika. Presented at the Yogyakarta (ID). Retrieved from:

https://www.researchgate.net/publication/320911024_PEMODELAN_REGRESI POISSON_DAN_BINOMIAL_NEGATIF_DAN_PADA_KASUS_KECELAKAAN_K ENDARAAN_BERMOTOR_DI_LALU_LINTAS_SUMATERA_BARAT

Melliana, A., Setyorini, Y., \& Eko, H. (2013). The comparison of generalized Poisson regression and negative binomial regression methods in overcoming overdispersion. International Journal of Scientific \& Technology, 8(2): 255-258.

Priyatno, D. (2013). Analisis korelasi, regresi dan multivariate dengan SPSS. Yogyakarta (ID): Gava Media.

Rahayu, D., Winahju, W. S., \& Mukarromah, A. (2012). Pemodelan pengaruh iklim terhadap angka kejadian demam berdarah dengue di Surabaya. Jurnal Sains Dan Seni ITS, 1(1): D69-D74.

Ruliana, Hendikawati, P., \& Agoestanto, A. (2016). Pemodelan Generalized Poisson Regression (GPR) Untuk Mengatasi Pelanggaran Equidispersi Pada Regresi Poisson Kasus Campak di Kota Semarang Tahun 2013. Unnes Journal of Mathematics, 5(1): 39-46. 